
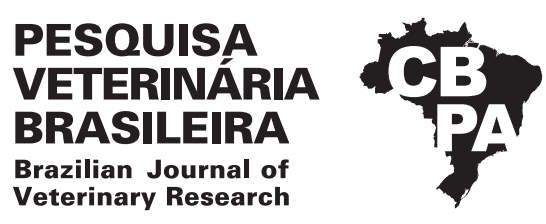

Pesq. Vet. Bras. 39(5):355-363, May 2019

DOI: 10.1590/1678-5150-PVB-5854

ISSN 0100-736X (Print)

ISSN 1678-5150 (Online)

\title{
Ultrasonographic, macroscopic and histological characterization of the proximal insertion of the suspensory ligament in Crioulo horses ${ }^{1}$
}

\author{
Grasiela De Bastiani ${ }^{2 *}$ (D) , Flávio D. De La Côrte², Karin Erica Brass², \\ Camila Cantarelli ${ }^{2}$, Ligia Maria M. Malfestio ${ }^{3}$, Daniela Schwingel ${ }^{3}$, \\ Taiara M. Silva ${ }^{4}$ and Glaucia Denise Kommers ${ }^{4}$ (D)
}

\begin{abstract}
De Bastiani G., De La Côrte F.D., Brass K.E., Cantarelli C., Malfestio L.M.M., Schwingel D., Silva T.M. \& Kommers G.D. 2019. Ultrasonographic, macroscopic and histological characterization of the proximal insertion of the suspensory ligament in Crioulo horses. Pesquisa Veterinária Brasileira 39(5):355-363. Departamento de Clínica de Grandes Animais, Universidade Federal de Santa Maria, Av. Roraima 1000, Santa Maria, RS 97105-900, Brazil.E-mail: grasibage@hotmail.com

Although ultrasound (US) is a routine diagnostic modality, it still presents limitations for the diagnosis of lesions such as those in the proximal insertion of the suspensory ligament (PISL) because of its composition, which includes muscle fibers and adipose tissue interspersed with the ligament fibers. The objective of the present study was to describe the ultrasonographic, macroscopic and histological aspects of the PISL of thoracic limbs (TL) and pelvic limbs (PL) in Crioulo horses (CH). We selected 34 specimens of TL (right and left) and 10 specimens of PL of horses with a mean age of 5.7 years, from a private clinic or sent to the Department of Veterinary Pathology of UFSM, which died from different causes. The animals had no previous history of lameness in selected limbs associated with PISL injuries. The 34 specimens of PISL of TL were divided into $\mathrm{CH}(\mathrm{n}=25)$ and Thoroughbred horses $(\mathrm{TBH})(\mathrm{n}=9)$, which composed the control group, and 11 specimens of PISL of PL were divided into $\mathrm{CH}(\mathrm{n}=8)$ and TBH $(n=3)$, which also served as control. The US examination was performed in the PISL using a Sonosite Edge device, 5-10 MHz linear transducer, with cross-sectional and longitudinal palmaromedial and palmarolateral images of the proximal surface of metacarpus III, II and IV (MCIII/MCII/MCIV). In PL, the evaluation was performed four centimeters below the chestnut in the plantaromedial aspect of metatarsus III and II (MTIII/MTII). PISL lobulated shape and size were compared with those of the contralateral limb, as well as the regularity of the palmar bone surface of MC III, II and IV. Subsequently, dissection of the PISL lobes was performed, as well as its macroscopic evaluation, which preceded the histological processing of the samples. In specimens of the $\mathrm{CH}$ breed, PISL showed echogenicity varying from peripheral dorsal hyperechogenic zones that merge into echogenic and hypoechogenic zones, where lobulation occurs. In the samples from the TBH group, PISL was also lobulated, but with differences in the echogenicity pattern such as diffuse hypoechogenicity and echogenicity. Macroscopically, $\mathrm{CH}$ samples presented a large amount of adipose tissue that corresponds to the dorsal peripheral zone of PISL, which ends in the connective tissue that delimits the ligamentous lobes. On a macroscopic cross-section of PISL, muscle fibers in red are mixed with white ligament fibers in the center of the ligament. This macroscopic finding was not observed in TBH samples, in which muscle fibers overlap ligament fibers throughout the ligament extension and a small amount of fat is present in the dorsal periphery of the ligament. PISL of PL had a triangular
\end{abstract}

\footnotetext{
${ }^{1}$ Received on August 15, 2018.

Accepted for publication on December 10, 2018.

2 Departamento de Clínica de Grandes Animais, Hospital Veterinário Universitário (HVU), Universidade Federal de Santa Maria (UFSM), Av. Roraima 1000, Campus Universitário, Santa Maria, RS 97105-900, Brazil. *Corresponding author: grasiela.bastiani@ufsc.br
}

\footnotetext{
${ }^{3}$ Departamento de Histologia, IMED, Rua Senador Pinheiro, Campus Passo Fundo, Passo Fundo, RS 99070-220, Brazil.

${ }^{4}$ Departamento de Patologia, Centro de Ciências da Saúde (CCS), Universidade Federal de Santa Maria (UFSM), Av. Roraima 1000, Campus Universitário, Santa Maria, RS 97105-900, Brasil.
} 
shape with echogenicity characteristics very similar to those observed in TL. In ultrasonographic, macroscopic and histological evaluation, PISL samples of TL and PL in CH showed a larger amount of peripheral dorsal adipose tissue, as well as a larger number of merged ligament and muscle fibers compared with those in TBH.

INDEX TERMS: Ultrasonography, macroscopic assessment, histology, proximal insertion, suspensory ligament, Crioulo horses, ultrasound, equine, horses.

RESUMO.- [Caracterização ultrassonográfica, macroscópica e histológica da inserção proximal do ligamento suspensório em cavalos Crioulos.] Embora uma modalidade diagnóstica rotineira, a ultrassonografia ainda possui algumas limitações para o diagnóstico de lesões como as que afetam a inserção proximal do ligamento suspensório (IPLS). Uma dessas limitações é relacionada à composição desse ligamento que inclui fibras musculares e tecido adiposo intercalados entre as fibras ligamentares. 0 objetivo do presente trabalho foi descrever os aspectos ultrassonográficos (US), macroscópicos e histológicos da IPLS de membros torácicos (MT) e membros pélvicos (MP) de equinos da raça crioulo (CC). Foram selecionados 34 espécimes de MT (direito e esquerdo) e 10 espécimes de MP de equinos com idade média de 5,7 anos, que vieram a óbito por diferentes causas, oriundos de uma clínica privada ou destinados ao Laboratório de Patologia Veterinária da UFSM. Não havia histórico prévio de claudicações nos membros selecionados que pudessem estar relacionadas a lesões da IPLS. Os 34 espécimes da IPLS MT foram divididos pela raça CC $(n=25)$ e Puro Sangue Inglês (PSI) $(n=9)$, o qual serviu como grupo controle e, 11 espécimes da IPLS do MP divididos em raça CC $(n=8)$ e PSI $(n=3)$ também como grupo controle. 0 exame US foi realizado na IPLS com um aparelho Sonosite Edge, transdutor linear de $5-10 \mathrm{MHz}$, com imagens transversais e longitudinais palmaromedial e palmarolateral da face proximal do metacarpiano (MC) III, II e IV. No MP a avaliação foi realizada quatro centímetros abaixo da castanha no aspecto plantaromedial do metatarsiano III e II (MTIII / MTII). Foram também observadas à forma lobulada da IPLS e o tamanho em comparação ao membro contralateral, bem como a regularidade da superfície óssea palmar do MC III, II, IV. Posteriormente foi realizada a dissecação dos lobos IPLS, bem como a avaliação macroscópica dos mesmos que antecedeu o processamento das amostras para histologia. Em espécimes CC, a IPLS possui uma ecogenicidade que varia de zonas periféricas dorsais hiperecogênicas que se mesclam a zonas ecogênicas e hipoecogênicas onde ocorre a sua lobulação. Nas amostras do grupo PSI, a IPLS também é lobulada, mas com diferenças no padrão de ecogenicidade como, hipoecogenicidade e ecogenicidade difusas. Macroscopicamente, as amostras CC apresentaram uma grande quantidade de tecido adiposo que corresponde à zona periférica dorsal da IPLS, a qual termina no tecido conjuntivo que delimita os lobos ligamentares. Em uma secção transversal macroscópica da IPLS as fibras musculares em vermelho se mesclam as fibras ligamentares brancas no centro do ligamento. Este achado macroscópico não foi observado na raça PSI, onde as fibras musculares intercalam as fibras ligamentares em toda a extensão do ligamento e pequenas quantidades de gordura estão presentes na periferia dorsal do mesmo. A IPLS no MP possui um formato triangular com características de ecogenicidade muito similares as citadas no MT. Na avaliação US, macroscópica e histológica as amostras da IPLS em MT e MP de equinos na raça CC demonstraram uma maior quantidade de tecido adiposo dorsal periférico bem como, uma maior quantidade de fibras musculares e ligamentares mescladas em comparação às amostras PSI.

TERMOS DE INDEXAÇÃO: Ultrassonografia, macroscopia, histologia, inserção proximal, ligamento suspensório, cavalos Crioulos, ultrassom, equinos.

\section{INTRODUCTION}

Lameness originating from the suspensory ligament (SL) is a common finding in performance horses (Dyson 1991). There are many studies in the literature addressing the diagnosis, occurrence, and treatment alternatives for proximal desmitis of the SL. However, when considering the main modality of their diagnosis - ultrasound (US) examination, changes in the SL associated with its structure and shape cannot always be easily differentiated from normal findings (Zauscher et al. 2013).

In the thoracic limb (TL), the SL originates in the proximal palmar aspect of metacarpus III (MCIII) (Gibson \& Steel 2002) and in the third carpal bone (Werpy et al. 2013), whereas in the pelvic limb (PL), the SL starts in the distal row of the tarsal bones and in the proximal plantar aspect of metatarsus III (MTIII) (Gibson \& Steel 2002), and it has the shape of a triangle (Werpy et al. 2013). An additional portion coming from the calcaneus is also described (Schulze 2007, Schulze \& Budras 2008).

US imaging is the most frequently used technique to assess of the suspensory apparatus (Carnicer et al. 2012). Although it was the imaging modality indicated for the evaluation of tendons and ligaments according to Denoix (1994), the interpretation of US images of the proximal insertion of the suspensory ligament (PISL) may become a challenge because of the diverse echogenicity found in this specific region. This diversity is due to the emergence of artifacts as a result of the unique histological composition of the SL, which has muscle fibers, that is why it is also called interosseous muscle III (Budras et al. 2003). This observation also stems from the different acoustic properties of the different tissues that compose the SL (O'Neil 2008). Muscle fibers are less echogenic than ligament fibers, creating a variation of echoes in the regular proximal insertion of the suspensory ligament (PISL) (Agut et al. 2009). In addition to muscle fibers, there is also fat, which is usually hyperechogenic (Bischofberger et al. 2006). However, the adipose tissue is often interspersed with muscle fibers within the ligament fascicles, contributing to variation in SL echogenicity (Schramme et al. 2012). The PISL consists of a strong tendinous band containing a variable amount of muscle tissue and fat (Dyson 1998). 
It is also composed of muscle fascicles surrounded by dense connective tissue (DCT) or, specifically, collagen bundles in a parallel arrangement of fibers. The surrounding loose connective tissue (LCT) could hardly be described as the classical perimysium, because it presents characteristics similar to those of the tissue surrounding the tendon tissue (Soffler \& Hermanson, 2006).

Interpretation of routine US examination of the PISL in Crioulo horses $(\mathrm{CH})$ can be difficult due to lack of information on its tissue composition, which directly influences its echogenicity pattern. To this end, this study aimed to describe the association of ultrasonographic, macroscopic and histological findings, thus providing a more accurate characterization of the PISL in the $\mathrm{CH}$ breed.

\section{MATERIALS AND METHODS}

We selected 34 specimens of TL and 10 specimens of PL of Crioulo (study group - $\mathrm{CH}$ ) and Thoroughbred (control group - TBH) horses that died from different causes at a mean age of 5.7 years, from a private equine clinic in southern Brazil, or that were sent to the Department of Veterinary Pathology of the Federal University of Santa Maria (UFSM). The TL specimens were disarticulated in the intercarpal region, whereas the PL specimens were disarticulated in the proximal intertarsal joint. The specimens were frozen at the origin, sent to the UFSM, and conditioned at $4^{\circ} \mathrm{C}$. US imaging was used to characterize the echogenicity, size, shape, and architecture of the PISL in $\mathrm{CH}$, and the images were compared with those obtained under the same conditions from the PISL in TBH. The specimens were trichotomized on the proximal palmar surface in the TL and proximal plantaromedial aspect below the chestnut in the PL. In order to facilitate passage of the US waves, the specimens were immersed in warm water and gel was used for better coaptation of the transducer to the skin. A stand-off pad was attached to the transducer to enlarge the contact surface between the transducer and the structure to be assessed. The US images were produced using a Sonosite device equipped with a 5-10 MHz linear transducer. Examination of the PISL of TL was performed through three approaches: a proximal, palmar cross-section, aiming to observe the two lobes together and the bone surface of MCIII in the same image and, in a second moment, observe each lobe separately in a palmaromedial and palmarolateral cross section, and a longitudinal and transverse section, examining the enthesis of MCIII between MCII and MCIV. Assessment of the PISL of PL was conducted using a cross-sectional and longitudinal palmaromedial image taken approximately $4 \mathrm{~cm}$ below the chestnut. Aiming to facilitate the US approach and maintain limb stance similar to the normal standing biomechanics, the specimens were placed in a hydraulic press under a force of 400-500kg. Criteria such as echogenicity, size, shape, architecture and enthesis of the PISL were evaluated for the $\mathrm{CH}$ and TBH breeds in the TL and PL. Specimens of both breeds that did not present changes in the US examination of the PISL were selected for the macroscopic and histological assessments. Subsequently, the medial and lateral lobes of the PISL were dissected in the proximal palmar region of the TL, approximately $2 \mathrm{~cm}$ below the carpometacarpal joint, and in the proximal palmaromedial region of the PL, approximately $4 \mathrm{~cm}$ below the chestnut. The medial and lateral lobes of the PISL of the TL were cross-sectioned, as well as the rounded lobe of the PL, and photographed for documentation. After that, the samples were fixed in $10 \%$ buffered formalin for 14 days. Soft tissue samples were routinely processed for histology in $3 \mu \mathrm{m}$-thick sections and stained with hematoxylin-eosin (HE).
Following, morphometric evaluation of the variables DCT, LCT, fat, and muscle fibers of the PISL was performed, and the results of the study $(\mathrm{CH})$ and control (TBH) groups were compared. The 34 PISL specimens of the TL were divided into $\mathrm{CH}(73.52 \%$; $\mathrm{X} / \mathrm{n}$ total $\mathrm{n}=25)$ and TBH $(26.37 \% ; \mathrm{X} / \mathrm{n}$ total $\mathrm{n}=9)$, whereas the 11 PISL specimens of the PL composed CH (72.77\%; $\mathrm{X} / \mathrm{n}$ total $\mathrm{n}=8)$ and TBH $(27.27 \% ; \mathrm{X} / \mathrm{n}$ total $\mathrm{n}=3)$.

Statistical analysis. In order to linearize the data, the variables DCT, LCT, fat, and muscle fibers were transformed into numerical variables and then into linear score $\left(\mathrm{LS}=\left[\log _{2}(\right.\right.$ variable $\left.\left.)\right]+3\right)$. After transformation into LS, the dependent variables (DCT, LCT, fat, and muscle fibers) were tested for residual normality by the Kolmogorov-Smirnov test and for homogeneity of variance using the Levene's test. Subsequently, they were submitted to univariate ANOVA using the framework for general linear models (PROC GLM) in a completely randomized design. Finally, the means were adjusted by the ordinary least squares method using the command LSMEANS (Least Squares Means) and compared with application of the Tukey's test at 5\% significance level. Statistical data were processed in the $\mathrm{SAS}^{\circledR}{ }^{\circledR}$ System for Windows ${ }^{\text {TM }}$ 9.0 software (Table 1 ).

\section{RESULTS \\ Ultrasound (US) examination}

The surfaces of MCIII, MCII, and MCIV of some specimens showed slight irregularities; however, they were included in this study because they did not present bone fragments and/or changes regarding echogenicity, shape, size and architecture of PISL.

PISL of CH had a lobular shape similar to that of TBH. As for size, it was observed that $73.52 \%$ of the PISL of CH showed no difference between lobes; however, in $26.47 \%$ of them, the medial lobe was larger comparison with the lateral lobe, and the same was observed for TBH. With respect to echogenicity, PISL of CH (Fig. 1A) was characterized by hypoechogenicity throughout the dorsal peripheral zone, which was also verified in the lobulation. The lobes were echogenic, interspersed with some hypoechogenic spots. In the TBH group (Fig.2A), the lobulated dorsal peripheral zone in direct contact with MCIII, $\mathrm{MCII}$, and MCIV was echogenic compared with that in the $\mathrm{CH}$ group. The PISL lobes in the TBH group were echogenic, more intensely interspersed with hypoechogenic area compared with those in the $\mathrm{CH}$ group. In the negative incidence on the PISL of CH (Fig.1B,C), some hyperechogenic lines and spots were evidenced in all its peripheral region; in some specimens,

Table 1. Comparison of the constitution of the proximal insertion of the suspensory ligament (PISL) between the study (Crioulo horses - $\mathrm{CH}$ ) and control (Thoroughbred horses - TBH) groups with respect to dense connective tissue (DCT), loose connective tissue (LCT), fat, and muscle fibers

\begin{tabular}{cccc}
\hline \multirow{2}{*}{ Variable } & \multicolumn{2}{c}{ Treatment } & \multirow{2}{*}{$p$ value* } \\
\cline { 2 - 3 } & Control (TBH) & Study $(\mathrm{CH})$ & \\
\hline DCT & $4.49(0.05)$ & $4.55(0.03)$ & 0.2953 \\
LCT & $3.08(0.06)$ & $3.03(0.04)$ & 0.4717 \\
Fat & $3.67(0.09)$ & $3.99(0.05)$ & 0.0038 \\
Muscle fibers & $3.88(0.14)$ & $3.67(0.09)$ & 0.2187
\end{tabular}

${ }^{*} p$ value $>0.05$ do not differ by the Tukey's test at $5 \%$ probability level; values in parentheses indicate standard error of the mean. 

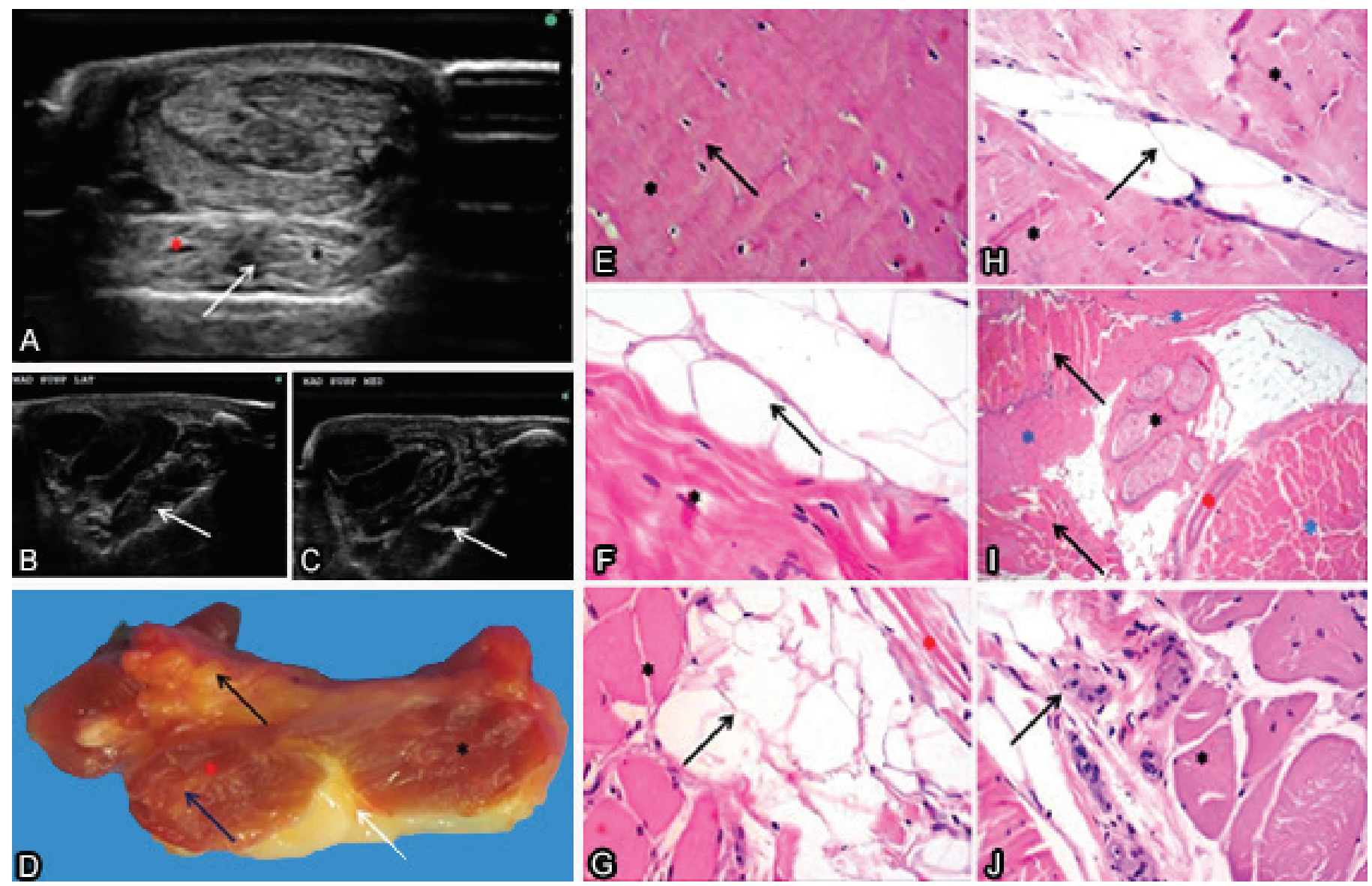

Fig.1. Proximal insertion of the suspensory ligament (PISL) of thoracic limb (TL) in the study group (Crioulo horse - CH). (A) Cross-sectional, proximal, palmaromedial (left) and palmarolateral (right) US images; hypoechogenicity of the peripheral region in the point where lobulation occurs (arrow). The lobes are echogenic, interspersed by some hypoechogenic spots (red asterisk, medial lobe; black asterisk, lateral lobe). (B) Cross-sectional, proximal lateral and (C) proximal medial, medial (left) and lateral (right) ultrasound (US) images; some hyperechogenic lines and spots are observed throughout the peripheral region reaching the interior of the lobe (arrows). They are not angle-negative dependent. (D) Gross cross-section; medial lobe (red asterisk), lateral lobe (black asterisk). Fat on the dorsal peripheral region (white arrow), inside the ligament (blue arrow), and in contact with the carpal joint (black arrow). (E) PISL composed of dense connective tissue - DCT (asterisk) and collagen fibers (arrow). HE, obj.20x. (F) Adipocytes are observed in the dorsal peripheral region (arrow), delimiting the loose connective tissue - LCT (asterisk). HE, obj.20x. (G) Adipocytes (black arrow) interspersed with muscle fibers (black asterisk) and LCT (red asterisk).HE, obj.20x. (H) Adipocytes (arrow) interspersed with the DCT (asterisk). HE, obj.20x. (I) PISL; ganglion nerve nuclei (black asterisk) between adipocytes (white arrow), delimited by LCT (red asterisk), DCT (blue asterisk), and bundles of muscle fibers (black arrow) are observed. HE, obj.20x. (J) Blood vessels (arrow) are observed between fascicles of muscle fibers (asterisk). HE, obj.20x.

these lines start from the periphery reaching the interior of the lobe, and they were not angle-negative dependent. This situation was not verified in the TBH group (Fig.2B,C), in which only subtle hyperechogenic spots were observed in the PISL peripheral region. In some specimens from younger $\mathrm{CH}$ breed animals (3.0 years old on average), the hypoechogenic area throughout the dorsal peripheral zone of the PISL was echogenic. In one specimen, of approximately six months of age, this situation did not occur; on the contrary, the dorsal peripheral region was markedly hypoechogenic, as previously described.

In the PL, the PISL of CH showed a rounded shape and was arranged under the surface of MTIII and the enthesis of MTII; it was echogenic, interspersed with hypoechogenic spots (Fig.3A). On its dorsal surface, there was a well-defined hypoechogenic region in close contact with the surface of
MTIII. In the TBH group (Fig.4A), the dorsal surface was echogenic and it was possible to observe a PISL in the shape of a triangle. In some specimens from $\mathrm{CH}$ and TBH, poorly delimited hyperechogenic zones were present within the SL, and hyperechogenic lines merged within the SL were also observed.

\section{Macroscopic assessment}

PISL of TL was observed in cross sections from the proximal dissection of the skin, superficial digital flexor tendon, deep digital flexor tendon, and the carpal joint. Macroscopically, the PISL of CH (Fig.1D) was divided into two well-defined lobes, medial and lateral, and no difference in size and shape was observed between the lobes. In specimens form the TBH group, the lateral lobe 

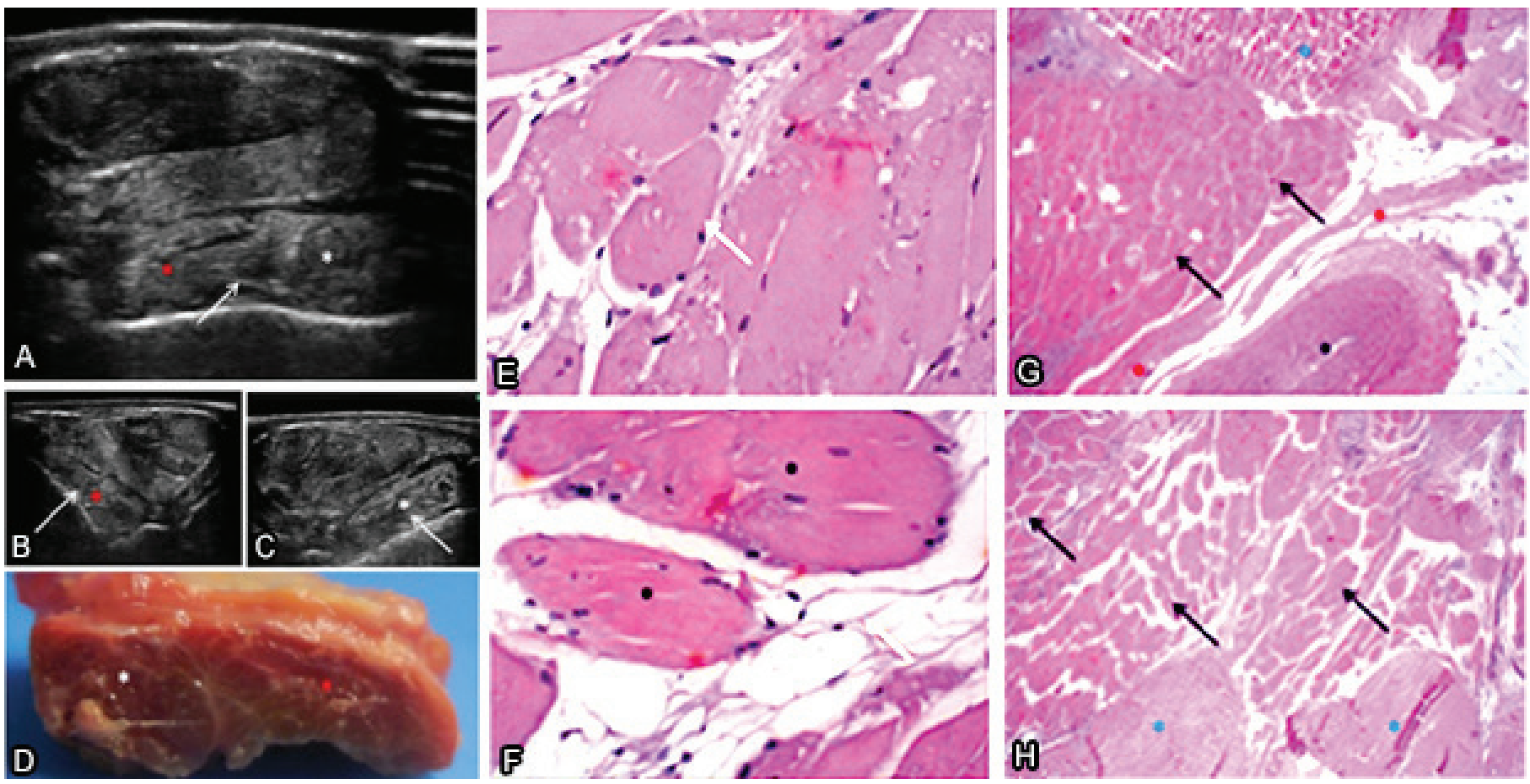

D

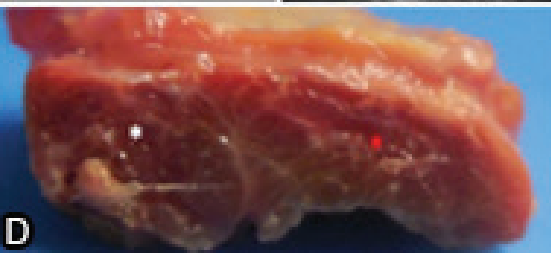

H

Fig.2. Proximal insertion of the suspensory ligament (PISL) of thoracic limb (TL) in the control group (Thoroughbred horse - TBH). (A) Cross-sectional, proximal, palmaromedial (left) and palmarolateral (right) ultrasound (US) images. Lobulated dorsal peripheral region in direct contact with MCIII (arrow). Medial (red asterisks) and lateral (white asterisks) lobes are echogenic, interspersed with hypoechogenic areas more intensely. Difference in size and shape is observed between them. Cross-sectional (B) proximal medial and (C) proximal lateral, medial (left) and lateral (right) US images; difference in size and shape between the medial (red asterisk) and lateral (white asterisk) lobes is observed. Subtle hyperechogenic spots located on the dorsal peripheral region in contact with metacarpus III - MCIII (arrow). (D) Gross cross-sectional; it can be observed that the lateral lobe is more rounded and prominent (white asterisk) compared with the medial lobe, which is flattened and thin (red asterisk). (E) Arrangement of fascicles of muscle fibers (arrow). HE, obj.20x. (F) Muscle fibers (asterisk) delimited by a small number of adipocytes (arrow). HE, obj.20x. (G) Fewer adipocytes (white arrow) are observed among the loose connective tissue - LCT (red asterisk), dense connective tissue - DCT (blue asterisk), muscle fiber fascicles (black arrow), and blood vessels (black asterisk). HE, obj.10x. (H) DCT (blue asterisk) delimited by a large number of muscle fiber fascicles (black arrow). HE, obj.10x.

was more rounded (Fig.2D) and prominent compared with the medial lobe, which was flatter and thinner. The PISL was in direct contact with MCIII and with its enthesis between MCII and MCIV. In the dissection of specimens of the $\mathrm{CH}$ group, a moderate layer of fat was observed in contact with the carpal joint. Observation of the same specimens in cross section showed a thick layer of fat on the dorsal peripheral zone of the SL (Fig.1D), which was yellowish in color and also filled the space where SL lobulation occurs. Adipose tissue was also often well delimited in the lobes. In contrast, no fat was found in the dorsal peripheral region in samples of the TBH group. A thin layer of fat was observed on the ventral border of the ligament in some cases of the TBH group. In only one TBH specimen location of adipose tissue was similar to that found in $\mathrm{CH}$ specimens. PISL color in $\mathrm{CH}$ varied from a light to off-white red, with fascicles well delimited by pearly white tissue similar to that observed in the tendinous tissue. Pearly white tissue can also be observed peripherally to the ligament in some cases. The palmar artery and palmar vein were observed, and they were supported by fat and the same pearly white tissue close to the PISL. Samples of the TBH group showed staining and organization of the fascicles similar to those verified in samples of the $\mathrm{CH}$ group.

Cross sections of PISL specimens were performed in the plantaromedial aspect of PL in order to observe the shape, fascicular architecture and staining of the composing tissues and the results were compared between the $\mathrm{CH}$ and TBH groups. PISL showed rounded shape in $\mathrm{CH}$ (Fig.3B) and triangular shape in TBH, with color varying from light to off-white red, in a few cases. The fascicles were clearly delimited by pearly white tissue. A thick layer of this tissue was observed on the dorsal margin of the SL in the TBH group (Fig.4B). In contrast, a thick layer of yellowish adipose tissue was identified in the PISL border in the $\mathrm{CH}$ group. In these $\mathrm{CH}$ specimens, fat was also focally located within the SL.

\section{Histological assessment}

In the samples of TL, the PISL was composed of DCT, and bundles of collagen fibers were observed (Figs.1E and $2 \mathrm{H}$ ). This tissue was delimited by LCT, which resulted in the formation of fascicles similar to the peritendon observed in the tendinous tissue. Adipocytes were densely present in the dorsal border of the PISL filling the space formed by their lobulation (Fig.1F). Adipocytes were also present inside 

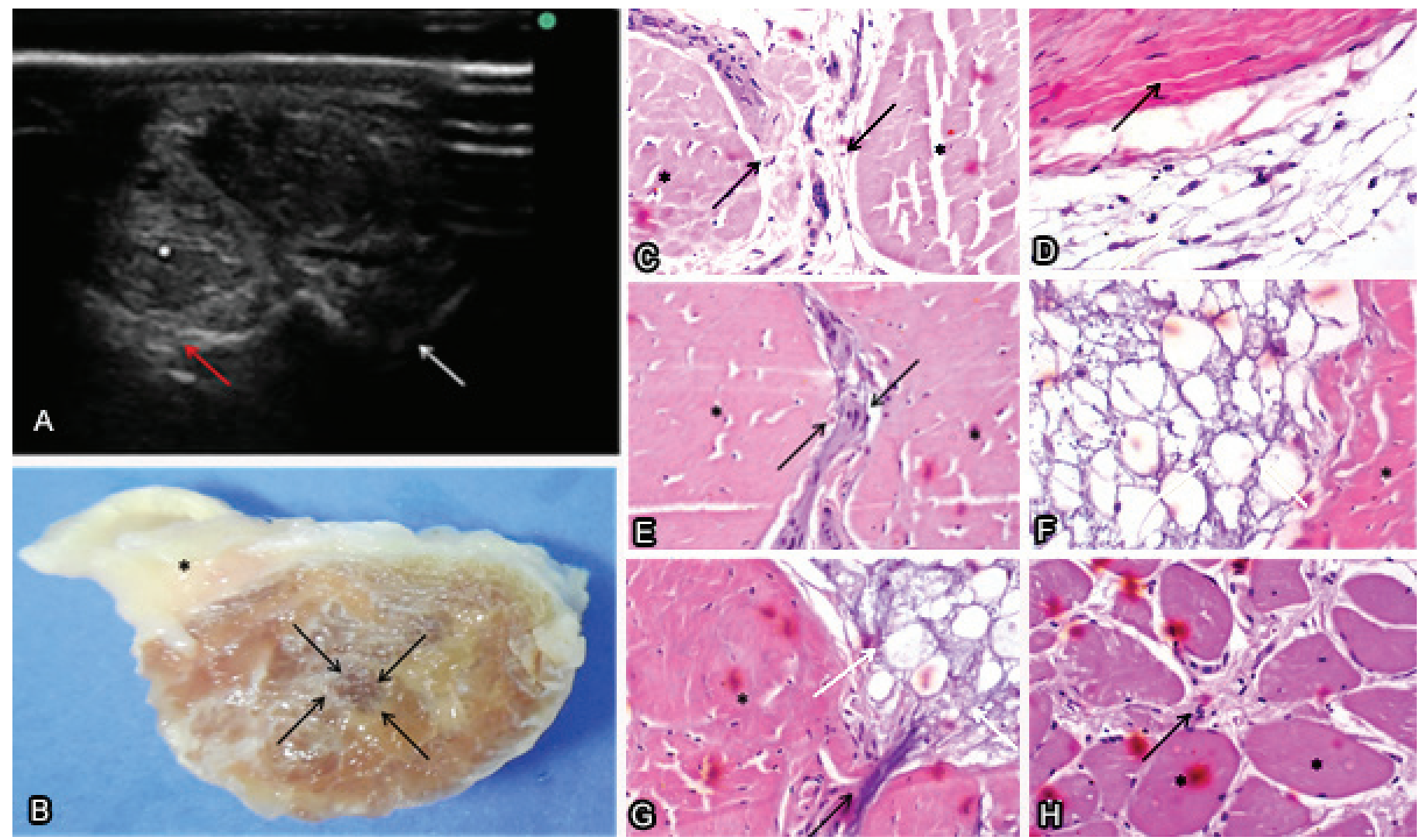

B

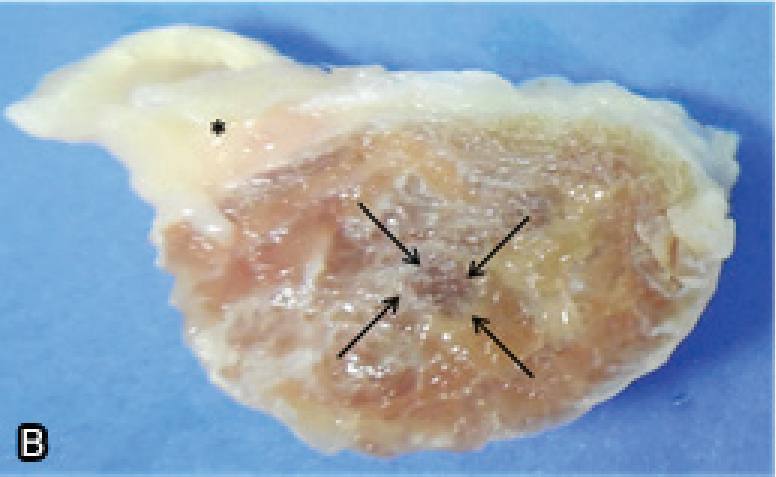

Fig.3. Proximal insertion of the suspensory ligament (PISL) of pelvic limb (PL) in the study group (Crioulo horse - CH). (A) Cross-sectional, plantaromedial (left and right) ultrasound (US) images. It is possible to observe a rounded SL (asterisk) arranged under the bone surface of metatarsus III - MTIII (white arrow) and the enthesis of MTII (red arrow), echogenic interspersed with hypoechogenic spots. (B) Gross cross-section. It is possible to observe a rounded suspensory ligament (SL) organized in fascicles (black arrow) and delimited by pearly white tissue (asterisk). (C-D) dense connective tissue (DCT) fascicles (asterisk) delimited by the loose connective tissue - LCT (arrow) are observed. HE, obj.20x. (E-G) Adipocytes (white arrow) arranged between the DCT (asterisk) and the LCT (black arrow). HE, obj.20x. (H) Muscle fiber fascicles (asterisks) are observed interspersed with the LCT (arrow). HE, obj.20x.

the lobes and, in some samples, delimited by muscle fiber fascicles and by DCT (Fig.1G,H), and LCT and DCT (Fig.1I). Numerous nerve ganglia (Fig. 1I) and blood vessels (Fig. 1J) were observed among adipocytes located on the dorsal border. Muscle fiber fascicles composed both groups and were mainly located inside the lobes surrounding the DCT and LCT (Figs.1I and 2E). An important characteristic observed in the TBH group refers to the smaller number of adipocytes per field evaluated subjectively (Fig.2G) compared with the $\mathrm{CH}$ group both in the border and inside the lobes.

Tissue composition and organization in the PISL in the PL samples are similar to those in the TL samples (Fig.3C,D). In the $\mathrm{CH}$ group, there was greater concentration of adipocytes per field (Fig. 3E-G) in the dorsal peripheral region of PISL and there were blood vessels and ganglion nerve clusters among them. In these specimens, muscle fiber fascicles (Fig.3H) were interspersed with adipocytes and delimited by LCT and DCT. In the TBH group, there was smaller concentration of adipocytes inside (Fig.4C), between muscle fiber fascicles (Fig.4D), and in the border (Fig.4E) of the PISL compared with that in the $\mathrm{CH}$ group. Greater concentration of muscle fiber fascicles was observed in the SL delimiting the DCT and
LCT (Fig.4F,G), as well as in the peripheral regions of the SL (Fig.4H) in the TBH group.

\section{DISCUSSION}

The selection criterion used in this study was based on the US, macroscopic and histological assessments of PISL specimens of the TL and PL of CH that were compared with those of TBH. Only data regarding the age and breed of the horses were obtained. The animals selected for this study did not have previous history of PISL-related lameness of the fore and hind limbs. The selected specimens did not show US changes compatible with PISL changes when compared with the contralateral limb. The choice of the US imaging as sample selection was due to the fact that it is the most frequently used modality in veterinary clinical routine for soft tissue evaluation. According to Carnicer et al. (2012), US is the most commonly used diagnostic imaging modality in the assessment of the suspensory apparatus, but interpretation of the images obtained from the PISL may vary because of its echogenicity. This diversity may be due to artifacts produced by the unique histological composition of the SL (Budras et al. 2003). It is worth considering that there are individual 

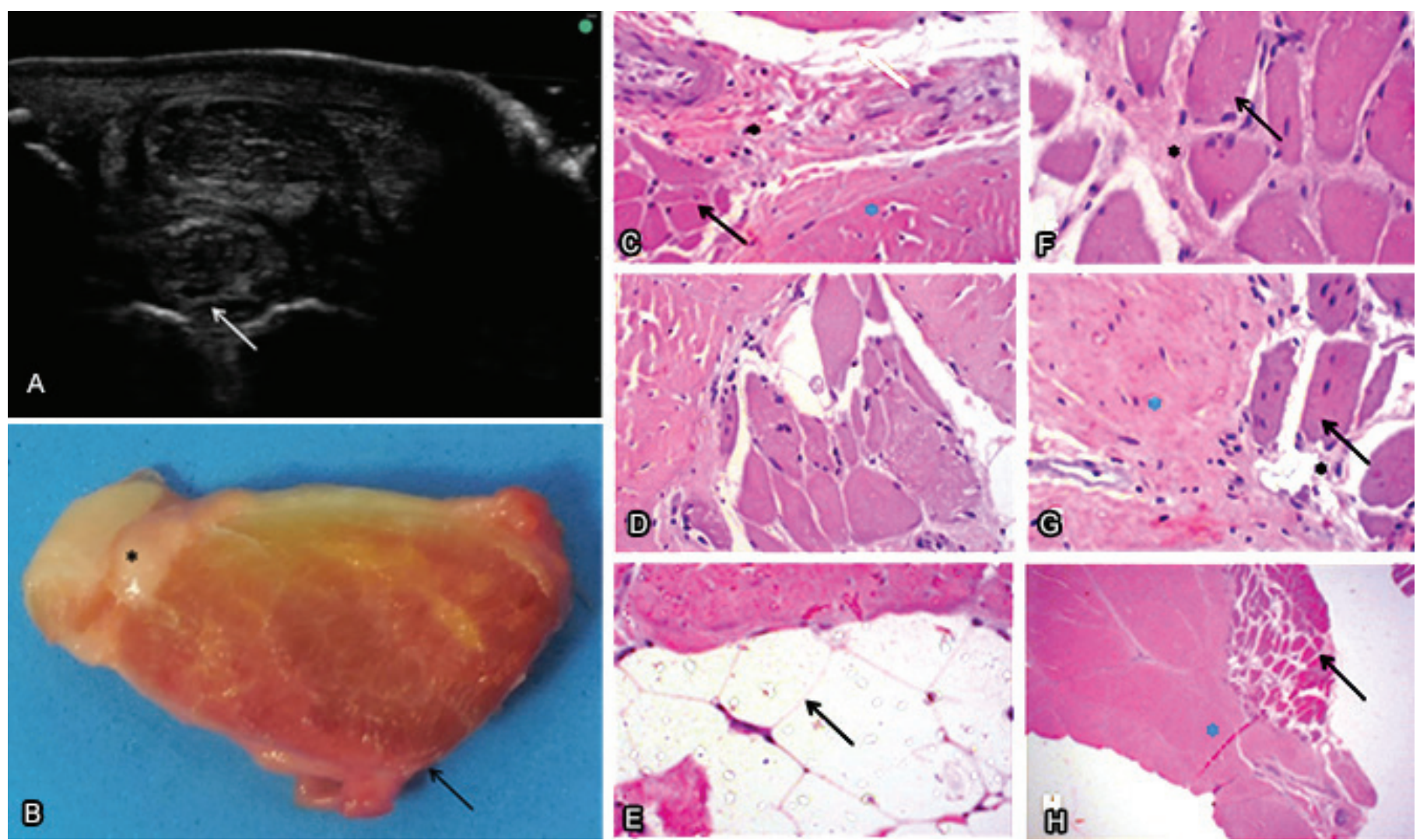

Fig.4. Proximal insertion of the suspensory ligament (PISL) of pelvic limb (PL) in the control group (Thoroughbred horse - TBH). (A) Cross-sectional, plantaromedial ultrasound (US) images. The dorsal peripheral zone of the echogenic suspensory ligament - SL (arrow) is observed. (B) Gross cross-section of the PISL. It is possible to observe the pearly white tissue that surrounds the SL (asterisk) and its triangular shape in light red (arrow). (C-D) A lower concentration of adipocytes in the SL among the loose connective tissue LCT (black asterisk), dense connective tissue - DCT (blue asterisk), and muscle fiber fascicles (black arrow) is observed. HE, obj.20x. (E) A small number of adipocytes are observed in the SL. HE, obj.20x. (F-G) Arrangement of muscle fiber fascicles (arrow) between the LCT (black asterisk) and the DCT (blue asterisk). HE, obj.20x. (H) The dorsal peripheral region of the SL with muscular fiber fascicles (arrow) and the DCT are observed. No adipocytes are observed. HE, obj.10x.

differences regarding the number of muscle fibers in the PISL, which can cause variation in US echogenicity (Zauscher et al. 2013). No statistically significant difference regarding the number of muscle fibers was observed between the $\mathrm{CH}$ and TBH groups ( $p=0.2187)$. However, an important histological feature is that muscle fiber fascicles were not peripherally present in the SL, but rather in the center of DCT fascicles, often delimited by the SL or by LCT and fat.

US diagnosis is used to differentiate changes in echogenicity as well as irregularities in the SL border (Imboden et al. 2009). Results reported by Reeding \& Scharamme (2007) demonstrated that US specificity is low when compared to magnetic resonance imaging (MRI) to document lesions associated with lameness originating in the plantar surface of MTIII. Nevertheless, Denoix et al. (2008) described the US technique as the most commonly used imaging modality in the investigation of Sl changes.

Muscle fibers are less echogenic than ligament fibers, creating a variation of echoes in the regular PISL (Agut et al. 2009). This variation was observed in specimens of the study and control groups in the present study, creating hypoechogenic spots or lines delimited within the SL in some evaluations. In US, the muscle fibers present lower echogenicity compared with that of the ligament fibers because of their tissue architecture, thus creating a variation in the pattern of produced echoes. Adipose tissue is hyperechogenic when the limb is in flexion, but when the limb is in bipodal stance, it is less echogenic than the ligament fibers. Corroborating Dyson (1998), the variable number of muscle fibers in the PISL could contribute to the production of hypoechogenic zones in the US images, thus hindering accurate US evaluation of the ligament architecture in the PISL. Echogenicity of the muscle fibers is smaller than that of the collagen fibers of the SL. In contrast, echogenicity of adipose tissue is not angle-negative dependent. Fat is hyperechogenic and may also present with echogenicity similar to that of the collagen fibers of the SL (Bischofberger et al. 2006).

According to Micklethwaite et al. (2001), US examination should be performed with the horse supporting the limbs on the ground, because if it is conducted without the weight tension in the ligaments and tendons, echogenicity can be reduced, possibly producing artifacts that can be mistaken for lesions. In this study, it was observed that when the limb was fully extended - a situation simulated by the press where the limbs were placed - adipose tissue was hypoechogenic; 
however, when full extension was not reached, similarly to the biomechanics of the animal, fat was hyperechogenic. These data were verified when, with the limb in full extension, a well delimited thick hypoechogenic line was observed in close contact with the surface of MCIII and its enthesis between MCII and MCIV, following the bifurcation area of the SL of TL, and became hyperechogenic when in slight flexion. In the gross assessment, it corresponded to thick yellowish adipose tissue present in the dorsal peripheral zone of PISL filling the space formed by its lobulation. Morphometric histological assessment showed $(p=0.0038)$ the presence of a large number of adipocytes interspersed with blood vessels and numerous nerve ganglia in the $\mathrm{CH}$ group. Adipocytes were also present in smaller number among the muscle fibers, LCT and DCT of the PISL. This composition was observed in 96\% of the samples from the CH group, and only one sample (4\%) did not present this characteristic. In contrast, these findings were not observed in the TBH group.

In the gross assessment, the organization of adipose tissue was not presented in the same way in some samples of the $\mathrm{CH}$ group where there was a thin layer in the aspect that is in close contact with the carpal joint. This finding was compatible with the histological evaluation, and adipocytes were also present between muscle fiber fascicles, LCT and DCT. As reported by Werpy et al. (2013), although the regions with presence of fat and muscle fibers are frequently located inside the lobes, they can be observed in histological sections dissecting the collagen fibers of the SL and located in the border. However, fat and muscle fibers are often interspersed within the SL, thus contributing to variation in their echogenicity (Schramme et al. 2012).

PISL of TL has a bilobed appearance, with the medial lobe usually thinner and wider than the lateral lobe (Werpy et al. 2013). In the TBH group, it was observed macroscopically that the medial lobe was wider and flatter and the lateral lobe was more rounded and prominent. This gross finding was not visualized in the $\mathrm{CH}$ group, with no differences in shape and size between the lobes. In the PISL of PL, the triangular shape of the SL is thinner medially than laterally, and is close to the MTIV, and separates from the MTII due to a greater amount of connective tissue (Werpy et al. 2013). This finding was observed macroscopically in both groups except that, in the $\mathrm{CH}$ group, there was a thick layer of peripheral fat that invaded the SL in most of the samples. In horse of the Standardbred breed, it was observed a larger number of muscle fibers in the SL of TL than in that of PL, and that this ratio is inverse in the TBH breed (Soffler \& Hermanson 2006). This difference was not observed between the $\mathrm{CH}$ and TBH groups.

PISL of TL and PL shows tissue organization in fascicles very similar to that observed in tendons. DCT is delimited by LCT and interspersed with muscle fibers and adipocytes. Histologically, as described by Schramme et al. (2012), the SL was composed of interfascicular spaces containing DCT and its collagen fibers.

The relationship between the US, macroscopic and histological findings of the PISL of TL and PL in the CH group, correlated with the findings for the TBH group, enables high accuracy in the interpretation of US images, providing information on tissue morphology and organization of the SL in $\mathrm{CH}$. These results enable better understanding of US images that do not correspond to PISL lesions, emphasizing the need for more comprehensive knowledge about the behavior of US changes and their possible misinterpretations.

\section{CONCLUSION}

The proximal insertion of the suspensory ligament (PISL) in horses of the Crioulo breed $(\mathrm{CH})$ shows individual characteristics with regards to its shape, size, and tissue composition and, consequently, is subject to echogenic variations. These findings are of fundamental importance for interpretation of ultrasound (US) images.

Acknowledgements.- The authors are grateful to Clínica Hípica (Dr. Jarbas Castro Jr. - in memoriam).

Conflict of interest statement.- The authors declare no competing interests.

\section{REFERENCES}

Agut A., Martinez M.L., Sánchez-Valverde M.A., Soler M. \& Rodríguez M.J. 2009. Ultrasonographic characteristics (cross-sectional area and relative echogenicity) of the digital flexor tendons and ligaments of the metacarpal region in Purebred Spanish horses. Vet. J. 180 (3):377-383. <http://dx.doi. org/10.1016/j.tvjl.2008.01.012> <PMid:18400531>

Bischofberger A.S., Konar M., Ohlerth S., Geyer H., Lang J., Ueltschi G. \& Lischer C.J. 2006. Magnetic resonance imaging, ultrasonography and histology of the suspensory ligament origin: a comparative study of normal anatomy of Warmblood horses. Equine Vet. J. 38(6):508-516. <http://dx.doi. org/10.2746/042516406X156109><PMid:17124840>

Budras K.D., Sack W.O. \& Röck S. 2003. Thoracic limb, p.2-13. In: Anatomy of the Horse. 4th ed. Editora K.-D, Hannover, Germany.

Carnicer D., Coudry V. \& Denoix J.M. 2012. Ultrasonographic examination of the palmar aspect of the pastern of the horse: sesamoidean ligaments. Equine Vet. Educ. 25(5):256-263. <http://dx.doi. org/10.1111/j.2042-3292.2012.00383.x>

Denoix J.M. 1994. Diagnostic techniques for identification and documentation of tendon and ligament injuries. Vet. Clin. North Am., Equine Pract. 10(2):365-407. <http://dx.doi.org/10.1016/S0749-0739(17)30361-9> $<$ PMid:7987723>

Denoix J.M., Coudry V. \& Jacquet S. 2008. Ultrsonographic procedure for a complete examination of the proximal third interosseus muscle (proximal suspensory ligament) in the equine fore limbs. Equine Vet. Educ. 3(3):148153. <http://dx.doi.org/10.2746/095777308X282381>

Dyson S. 1991. Proximal suspensory desmitis: clinical, ultrasonographic and radiographic features. Equine Vet. J. 23(1):25-31. <http://dx.doi. org/10.1111/j.2042-3306.1991.tb02708.x> <PMid:2015804>

Dyson S. 1998. Suspensory apparatus, p.447-475. In: Rantanen N. \& McKinnon A. (Eds), Equine Diagnostic Ultrasonography. Blackwell Publishing, Oxford.

Gibson K.T. \& Steel C.M. 2002. Conditions of the suspensory ligament causing lameness in horses. Equine Vet. Educ. 14(1):39-50. <http://dx.doi. org/10.1111/j.2042-3292.2002.tb00137.x>

Imboden I., Waldern N.M., Wiestner T., Lischer C.J., Ueltschi G. \& Weishaupt M.A. 2009. Short term analgesic effect of extracorporeal shock wave therapy in horses with proximal palmar metacarpal/plantar metatarsal pain. Vet. J. 179(1):50-59. <http://dx.doi.org/10.1016/j.tvjl.2007.09.020> <PMid:18069025>

Micklethwaite L., Wood A.K., Sehgal C.M., Polansky M., Dowling B., Dart A., Rose R. \& Hodgson D. 2001. Use of quantitative analysis of sonographic brightness for detection of early healing of tendon injury in horses. Am. J. 
Vet. Res. 62(8):1320-1327.<http://dx.doi.org/10.2460/ajvr.2001.62.1320> <PMid:11497458>

O’Neil J.M.D. 2008. Musculoskeletal ultrasound: anatomy and technique. Springer, New York. <http://dx.doi.org/10.1007/978-0-387-76610-2>.

Reeding W.R. \& Scharamme M.C. 2007. The use of MRI in the diagnosis of proximal plantar metatarsal pain in 22 horses. Proceedings of the 16th Annual Scientific Meeting of the European College of Veterinary Surgeons, Dublin, Ireland, p.170-174. (Resumo)

Schramme M., Josson A. \& Linder K. 2012. Characterization of the origin and body of the normal equine rear suspensory ligament using ultrasonography, magnetic resonance imaging, and histology. Vet. Radiol. Ultrasound 53(3):318-328. <http://dx.doi.org/10.1111/j.1740-8261.2011.01922.x> $<$ PMid:22332890>

Schulze T. 2007. Magnetresonanztomographische, computertomographische und histologische Untersuchung zum M. interosseus medius der Beckengliedmaße des Pferdes. Vet. Med. Diss. Berlin.
Schulze T. \& Budras K.-D. 2008. About the clinical and functional anatomy of the suspensory ligament (M. interosseus medius) in the hind limb in relation to high suspensory desmitis of the horse. Pferdeheilkunde Equine Medicine 24(3):343-350. <http://dx.doi.org/10.21836/PEM20080306>

Soffler C. \& Hermanson J.W. 2006. Muscular design in the equine interosseus Muscle J. Morphol. 267(6):696-704.<http://dx.doi.org/10.1002/jmor.10433> $<$ PMid:16511864>

Werpy N.M., Denoix J.M., Mcilwraith C.W. \& Frisbie D.D. 2013. Comparison between standard ultrasonography, angle contrast ultrasonography, and magnetic resonance imaging characteristics of the normal equine proximal suspensory ligament. Vet. Radiol. Ultrasound 54(5):536-547. <http:// dx.doi.org/10.1111/vru.12051><PMid:23718137>

Zauscher J.M., Estrada R., Edinger J. \& Lischer C.J. 2013. The proximal aspect of the suspensory ligament in the horse: How precise are ultrasonographic measurements? Equine Vet. J. 45(2):164-169. <http:// dx.doi.org/10.1111/j.2042-3306.2012.00597.x><PMid:22784195> 